\title{
Occurrence of a prothoracicotropic hormone-like peptide in the developing nervous system of the honey bee (Apis mellifera $\mathbf{L}$ )
}

\author{
ZL Paulino Simões ${ }^{1 *}$, IC Boleli ${ }^{1}$, K Hartfelder ${ }^{2}$ \\ ${ }^{I}$ Faculdade de Filosofia Ciências e Letras de Ribeirão Preto, Universidade de São Paulo, \\ Av Bandeirantes 3900, 14040-90I, Ribeirão Preto, SP, Brazil; \\ ${ }^{2}$ Zoologisches Institut, Universität Tübingen, Auf der Morgenstelle 28, \\ D-72076 Tübingen, Germany
}

(Received 21 July 1997; accepted 27 September 1997)

\begin{abstract}
Summary - An antibody generated against prothoracicotropic hormone (PTTH) of the silkworm Bombyx mori reacted with distinct sets of cells in the central nervous system and also in the retrocerebral complex of Apis mellifera larvae and pupae. Neurons expressing a Bombyx-PTTH-like peptide were first detected in the spinning stage of the last larval instar. Five distinct clusters of brain neurons comprising a total of 20-24 neurons were stained in this larval stage, in addition to a pair of somata located in the labial neuromere and in the first thoracic ganglion. With progressing metamorphosis this pattern changed. In white-eyed pupal brains only two neurons in the dorsal protocerebrum continued to express a PTTH-like peptide, whereas in the suboesophageal ganglion each neuromere now contained a pair of immunoreactive neurons. No axonal PTTH immunoreactivity was detected.
\end{abstract}

PTTH / insect neuropeptide / corpora allata / insect metamorphosis / Apis mellifera

\section{INTRODUCTION}

Insect postembryonic development is coordinated by precise regulation of the release of neurosecretory brain peptides, in particular prothoracicotropic hormone (PTTH). After release into the haemolymph, PTTH activates the prothoracic glands to synthesize ecdysteroids that in turn induce and synchronize molting and metamorphosis in the epidermis and other target tissues (Bollenbacher and Granger, 1985; Bollenbacher et al, 1993). Structural and functional analysis of PTTH has most successfully been per-

\footnotetext{
* Correspondence and reprints
}

Tel: (55) 16 6023805; fax: (55) 166336482 ; e-mail: zlpsimoe@usp.br 
formed in lepidopteran insects, especially the silkworm, Bombyx mori, where several prothoracicotropic peptides have been cloned and sequenced [for a review see Ishizaki and Suzuki (1992)], and expression patterns of the PTTH gene have been investigated (Adachi et al, 1994). Bombyx PTTH is now considered to be a new member of the vertebrate growth factor superfamily (Noguti et al, 1995). The physiological role of PTTH in insect development has mainly been investigated using the tobacco hornworm, Manduca sexta, as a model (Gilbert, 1989). In this moth, PTTH has been physically characterized (Muehleisen et al, 1994), and a partial amino acid sequence has been obtained, which showed sequence homology with cellular retinoid binding proteins, but surprisingly not with Bombyx PTTH (Muehleisen et al, 1993). While differing at their active sites, Bombyx and Manduca PTTH nevertheless appear to be immunologically related at their $\mathrm{N}$-terminus (Rybczynski et al, 1996). Prothoracicotropic peptides have also been partially purified not only in other lepidopterans, such as the European cornborer, Ostrinia nubilalis (Gelman et al, 1992), and the gypsy moth, Lymantria dispar (Kelly et al, 1995), but also in the cockroach, Periplaneta americana (Richter, 1992), and in Drosophila melanogaster (Pak et al, 1992).

Immunocytochemical identification of PTTH-immunoreactive cells and their axons has considerably improved our knowledge on the structural organization of these neurons in the neuroendocrine axis of insects (O'Brien et al, 1988; Mizoguchi et al, 1990; Westbrook et al, 1991; Goltzené et al, 1992; Zitnan et al, 1993; Dai et al, 1994), and advanced our understanding of the development of the insect central nervous system (Westbrook and Bollenbacher, 1990). Furthermore, they provided information on the programming of diapause, an important aspect of an insect's life cycle. In Manduca sexta, diapause is induced by a reprograming of a photoperiodic clock (Bowen et al,
1984). This eventually postpones, apparently by glia-neuron signaling (Hartfelder et al, 1994), the release of PTTH from the prothoracicotropic neurons.

Embedding postembryonic development into an insect's life history, thus appears to be an important aspect of PTTH function. Not surprisingly, therefore, peptides controlling activity patterns in the endocrine system are also hypothesized to play a role in another evolutionary highly successful life history strategy, namely reproductive division of labor in social insects resulting from the differentiation of morphologically distinct castes during metamorphosis. Ecdysteroid titers have been shown to be castespecifically modulated in the honey bee (Rachinsky et al, 1990), with differences in ecdysteroid titer reflecting a caste-specific program of prothoracic gland activity (Hartfelder, 1993). Since topical applications of synthetic juvenile hormone to early fifthinstar worker larvae induced a shift in the developmental profile of the ecdysteroid titer from a worker- to a queen-like pattern (Rachinsky and Engels, 1995), and since ecdysteroids have been shown to control the expression of specific proteins in the developing honey bee ovary (Hartfelder et al, 1995), understanding the regulation of prothoracic gland activity becomes an important issue in caste development. In this study, we report the immunocytochemical identification of neurons expressing a PTTH-like peptide in the central nervous system and the retrocerebral complex of the honey bee during larval and early pupal development.

\section{MATERIALS AND METHODS}

\section{Animals and tissue preparation}

Last instar larvae and white-eyed pupae were obtained from colonies of Apis mellifera kept in our experimental apiaries at Tübingen and Ribeirão Preto. Entire ventral nerve cords, or 
brains with the retrocerebral complex and suboesophageal ganglion remaining attached were dissected in sterile saline solution, and immediately fixed in Bouin's fixative for $2 \mathrm{~h}$ at room temperature. After fixation, the tissues were rinsed overnight in $0.05 \mathrm{M}$ PBS (phosphatebuffer $0.05 \mathrm{M}, \mathrm{pH} 7.4$, containing $0.15 \mathrm{M} \mathrm{NaCl}$ and $0.1 \%$ sodium azide), dehydrated, and embedded in paraplast. Serial $10-\mu \mathrm{m}$ sections were mounted on gelatin-coated slide, deparaffinized in xylene, and rehydrated in a graded alcohol series for immunocytochemical localization of PTTH.

\section{Immunocytochemistry}

Neurons expressing a PTTH-like peptide were identified using an antiserum generated in rabbit against the $\mathrm{N}$-terminal amino acid sequence of Bombyx mori PTTH (Mizoguchi et al, 1990). Immunocytochemical staining was performed by a peroxidase-antiperoxidase reaction.

Sections were first immersed in $3 \% \mathrm{H}_{2} \mathrm{O}_{2}$ in $100 \%$ methanol for $5 \mathrm{~min}$ to remove endogenous peroxidase activity. After this treatment, sections were washed in PBS-B-T (PBS containing 0.1\% BSA and $0.2 \%$ Triton X-100), Bombyx moriPTTH antiserum (diluted 1:200) PBS-B-T) was added to the sections for $16 \mathrm{~h}$ at $4{ }^{\circ} \mathrm{C}$. Following three short PBS-B-T rinses, sections were first incubated for $60 \mathrm{~min}$ at room temperature with a pig-anti-rabbit IgG antiserum (DAKO A/S, Glostrup, Denmark), and after being washed in PBS-B-T for $10 \mathrm{~min}$ they were incubated with peroxidase-antiperoxidase (PAP) complex (DAKO) for $60 \mathrm{~min}$. Following two short rinses in PBS-B-T and in Tris- $\mathrm{HCl}(0.05 \mathrm{M}, \mathrm{pH} 7.6)$, sections were reacted with $0.05 \% 3.3^{\prime}-$ diaminobenzidine tetrahydrochoride (SIGMA) diluted in Tris- $\mathrm{HCl}$ containing $0.01 \%$ imidazole, $0.4 \% \mathrm{NiCl}_{2}$ and $0.015 \% \mathrm{H}_{2} \mathrm{O}_{2}$. The reaction was terminated after $2-6 \mathrm{~min}$ by rinsing the slides in PBS. Alcohol-dehydrated sections were mounted in Entellan (SERVA). Specificity of the immunoreaction was checked in control experiments in which the first antibody specific for PTTH was omitted. Specimens were viewed and photographed on a Zeiss photomicroscope equipped with differential-interference-contrast optics. Drawings were made with a camera lucida attachment.

\section{RESULTS}

The presence of a potentially prothoracicotropic peptide in the brain-retrocerebral complex and the ventral ganglia of honey bee (Apis mellifera) larvae and pupae corresponded to the reactivity to an antibody raised against the $30-\mathrm{kDa}$ PTTH of the silkworm, Bombyx mori (Mizoguchi et al, 1990). It was only at the end of the spinning phase in the fifth larval instar that neurons started to exhibit PTTH immunoreactivity for the first time (fig 1 ). In this stage, a PTTH-like peptide was expressed in 20-24 somata in the brain. Based on analyses of serially sectioned brains of worker larvae, these neurons could be grouped into five distinct sets in each brain hemisphere (fig 2A). Cluster 1 consists of a single PTTH-immunoreactive neuron located in the dorsal protocerebrum dorsally to the upper anterior fold of the lamina ganglionaris. A group of three neurons representing cluster 2 is in a more medial position in the protocerebrum, between the lamina and medulla of the expanding optic lobes and adjacent to the developing mushroom body calces. Cluster 3 is less well defined and consists of 2-4 neurons distributed along the lateral margin of the optic lobe. Two neurons situated in the ventromedial protocerebrum between the oesophageal foramen and the protocerebral bridge were denominated as cluster 4 . Finally, cluster 5 consists of two PTTH-immunoreactive somata that are located in the deutocerebrum close to the developing antennal structures.

In addition to the somata in the larval brain, PTTH-immunoreactive cells were also detected in the suboesophageal ganglion (fig 1D). Serial sectioning revealed that there are two bilaterally symmetric cells expressing a PTTH-like peptide in the labial neuromere (fig $2 B$ ). In the segmental ganglia of the ventral nerve cord, it was only in the prothoracic ganglion that we could detect PTTH-immunoreactive cells (figs $1 \mathrm{E}$ and $2 C)$. These were found located in a similar 

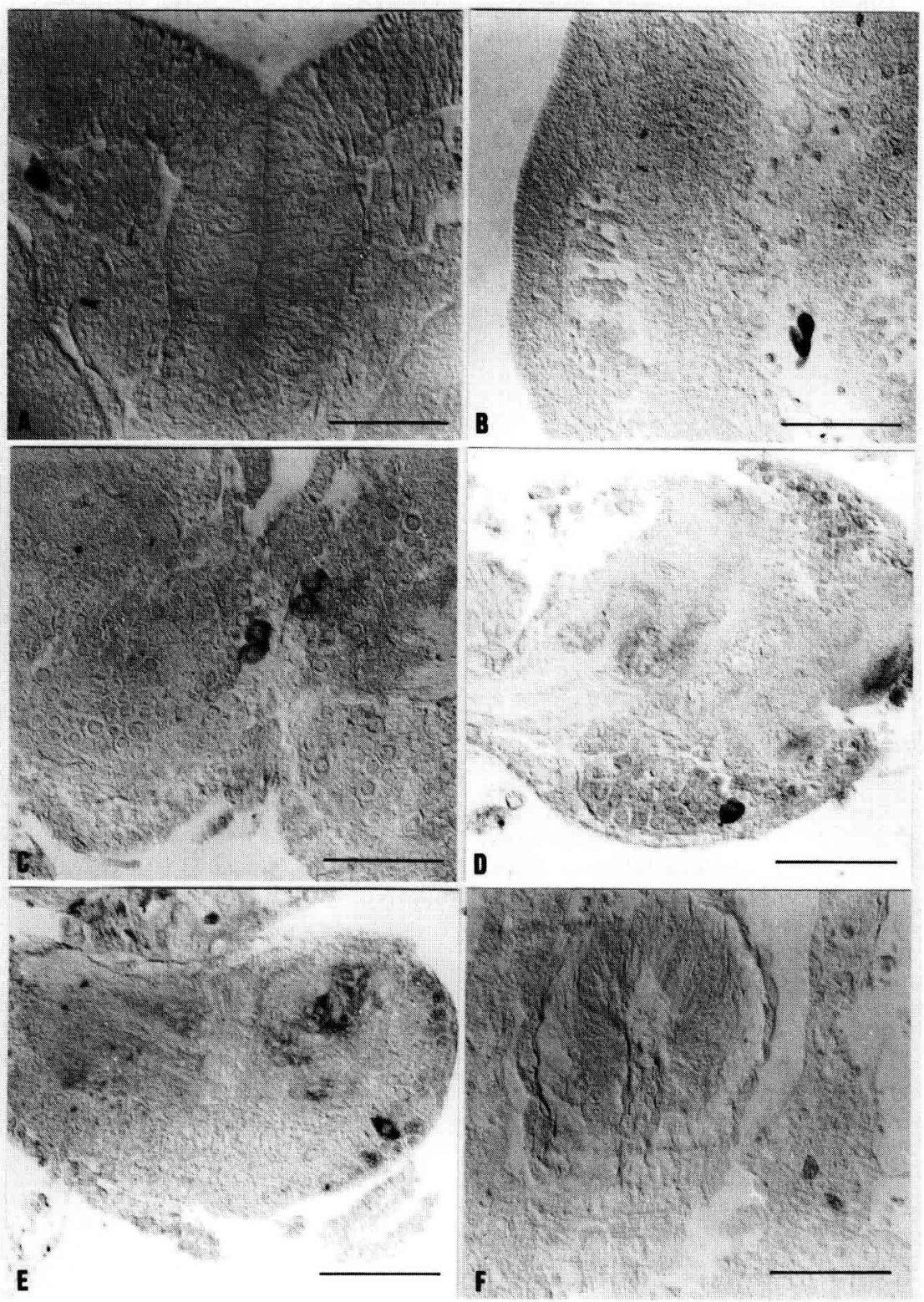

Fig 1. Immunohistochemical localization of a Bombyx mori PTTH-like peptide in the brain, retrocerebral complex, suboesophageal ganglion, and first thoracic ganglion of Apis mellifera spinning-phase fifth instar larvae: (A) somata of a cluster 1 neuron in the dorsal protocerebrum; (B) somata of cluster 2 neurons in the mediodorsal protocerebrum; (C) two pairs of immunoreactive somata (cluster 4 ) in the ventromedial protocerebrum; (D) PTTH immunoreactive cells in the suboesophageal ganglion, and (E) in the first thoracic ganglion; (F) cell expressing a PTTH-like peptide in the ventral bridge connecting the paired corpora allata below the oesophagus (scale bars: $\mathrm{A}, \mathrm{B}, \mathrm{C}, \mathrm{D}, \mathrm{E}=1 \mu \mathrm{m} ; \mathrm{F}=0.4 \mu \mathrm{m}$ ). 
position as the somata in the preceding labial neuromere.

With the first metamorphic molt this picture changed quite dramatically. First, the total number of PTTH-immunoreactive cells in the brain was reduced from 24 neurons in the brain of spinning-phase larvae to only two neurons in the brain of white-eyed pupae (fig 3). Whether these neurons correspond to the cluster 1 somata of the larval brain awaits further experimental analysis, because with the extension of the optic lobes and growth of the mushroom bodies, the pupal PTTH-immunoreactive neurons could have acquired a more medial position in the dorsal protocerebrum, laterally in the pars intercerebralis. The number of PTTHimmunoreactive neurons in the suboesophageal ganglion also changed after the pupal molt. In addition to a pair of somata in the labial neuromere, neurons in corresponding postions in the maxillary and mandibular neuromeres also acquired this phenotype.

Since we could not detect PTTHimmunoreactive material in axons descending from the immunostained brain somata we were unable to map the architecture of
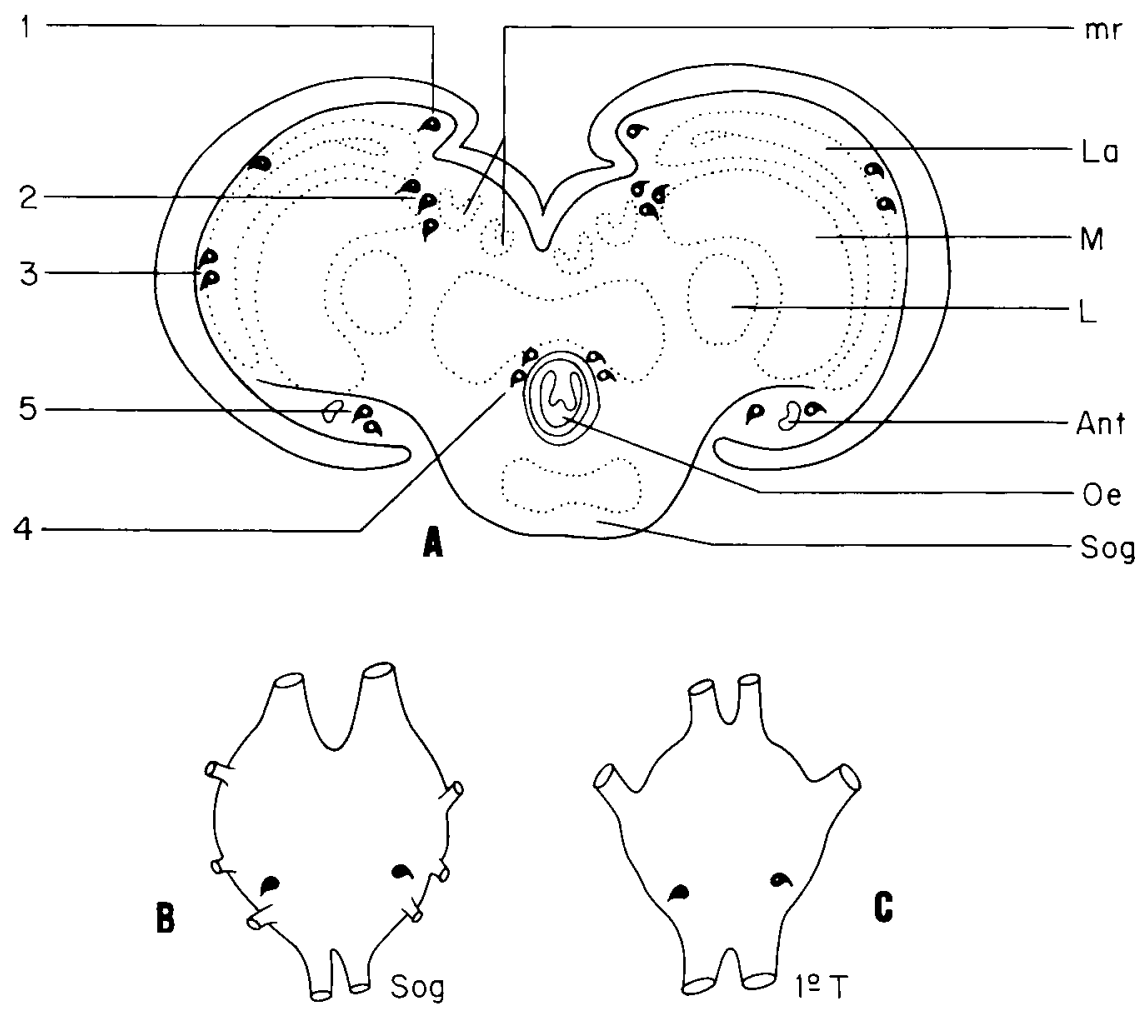

Fig 2. Schematic illustration reconstructed from serial paraffin sections of neurons expressing a Bombyx mori PTTH-like peptide in the brain (A), suboesophageal ganglion (B), and first thoracic ganglion (C) of an Apis mellifera spinning-phase larvae. Ant, antennal disc; L, lobula; La, lamina; M, medulla; mr, mushroom bodies; Oe, oesophagus; Sog, suboesophageal ganglion; 1-5, cluster denomination of PTTH-immunoreactive cells; 1st, first thoracic ganglion. 


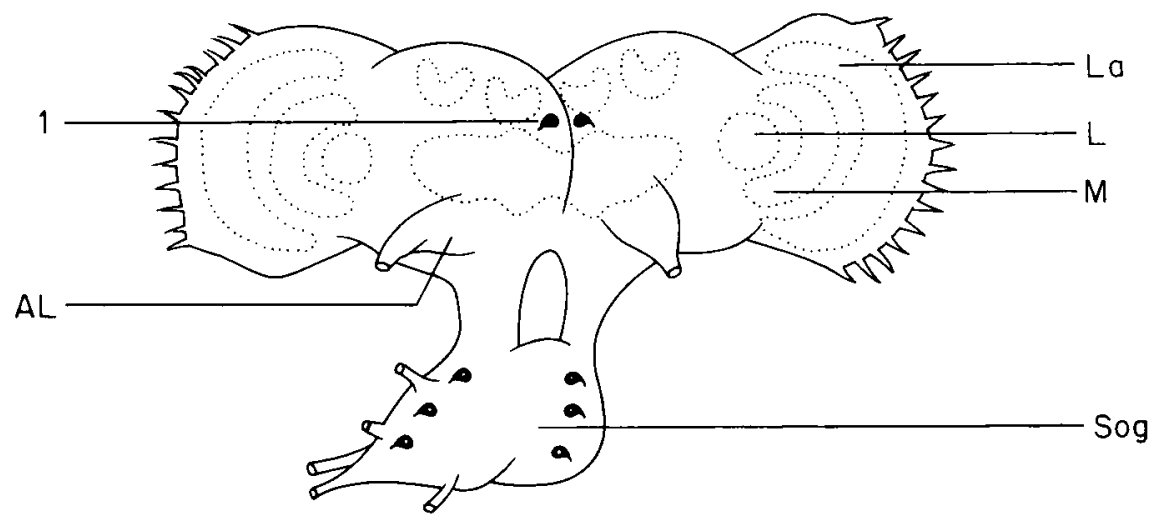

Fig 3. Schematic illustration of neurons expressing a Bombyx mori PTTH-like peptide in the brain and suboesophageal ganglion of an Apis mellifera white-eyed pupae. AL, antennal lobe; L, lobula; La, lamina; $M$, medulla; Sog, suboesophageal ganglion.

these neurons. Hence, information regarding release sites of a PTTH-like peptide into the hemolymph from a retrocerebral neurohemal organ could not be obtained in this study. In serial sections of the corpora cardiaca and corpora allata, we were, however, able to detect a small number of PTTHimmunoreactive cells located in a bridge structure that connects the paired corpora allata ventrally of the oesophagus (fig 1F). These cells were found directly adjacent to the corpora allata, close to the anterior end of the aorta.

\section{DISCUSSION}

Neurons expressing a PTTH-like peptide were identified in the brain, the suboesophageal neuromeres, and the prothoracic ganglion of last instar larval and pupal honey bees. Due to the peptide's well-documented central function in controlling molting cycles and metamorphosis in the Lepidoptera, comparative analyses on occurrence and distribution of PTTH-like peptides in the central nervous system of different orders of insects could shed light on possible functions of neurons expressing related peptides in specific insects.

Viewed from this perspective, certain PTTH-immunoreactive cells in the larval and pupal honey bee brain could be considered as homologs to the functionally and developmentally better described PTTH neurons in moths. Homolgy of the two large PTTH-immunoreactive neurons (cluster 1) in the larval and pupal honey bee protocerebrum with the lateral neurosecretory group III (L-NSC III) neurons of Manduca sexta (Westbrook et al, 1991, 1993), and with the corresponding neurons in Bombyx mori (Mizoguchi et al, 1990) is suggested by their localization within the brain, as well as by the fact that they are the only neurons in the dorsal protocerebrum that continually produce a PTTH-like peptide. Timing of appearence of this peptide in the dorsolateral neurons, coincides with increases in the hemolymph ecdysteroid titer (Rachinsky et al, 1990), as well as in prothoracic gland activity in honey bee larvae (Hartfelder, 1993). Since, however, we could not detect axonal PTTH-immunoreactive material in the honey bee brain, functional equivalence 
with the lepidopteran prothoracictropic neurons is not established, and caution is warranted when proposing a role of these neurons in the control of ecdysteroid synthesis in the honey bee prothoracic gland. Conclusions from interspecific comparisons on PTTH function are further complicated by the apparent lack of conservation of the peptide's structure; Bombyx PTTH, for example, does not stimulate ecdysteroid secretion in Manduca sexta prothoracic gland preparations (Muehleisen et al, 1993), even though Bombycidae and Sphingidae are fairly closely related lepidopteran families. Recent elegant experiments by Rybczynski et al (1996) using immuno in vitro assays, however, showed that the antibody against Bombyx PTTH recognizes Manduca PTTH, and blocks its effects on prothoracic glands. Rybczynski et al (1996) suggest that Bombyx and Manduca PTTH share sequence homology at the terminus, but that the putative receptor binding sites may have diverged, so that the two peptides do not exhibit functional interspecific activity. This class of peptide may thus be more conserved than expected, a fact which is also supported by the detection of PTTH-immunoreactive neurons with the Bombyx PTTH antibody in insects other than lepidopterans (Zitnan et al, 1993), and by the recent three-dimensional models of Bombyx PTTH (Noguti et al, 1995).

Functional interpretations from neuroanatomical evidence have to take into account the possibilty that a number of neuropeptides can be coexpressed in functionally identified neurons. In insects, prime examples for peptide coexpression are the LNSC III of Manduca sexta, where a 28-kDa peptide and Bombyx PTTH are expressed in addition to authentic Manduca PTTH (Gray et al, 1993, 1994). Similar observations have been made for the ventromedial neurosecretory cells (VM-NSC). The VMNSC of Manduca sexta are known to control eclosion activity (Copenhaver and Truman, 1986). They express, however, not only eclosion hormone but also show immunoreactivity against Manduca sexta PTTH (Westbrook et al, 1993). In the honey bee larval brain, two bilaterally symmetric pairs of PTTH-immunoreactive neurons were detected in the ventromedial protocerebrum (cluster 4 neurons). By position and temporal caracteristics of PTTH-like peptide expression, these neurons could be homologs of the Manduca VM-NSC.

The number of PTTH-immunoreactive neurons in the honey bee brain was observed to change during development. With the progression of metamorphosis, only one neuron per brain hemisphere continued to express the PTTH phenotype indicating cessation of the peptide's expression in many pupal neurons. Cessation of the synthesis of a particular neuropeptide has been demonstrated for Manduca neurons coexpressing bursicon and a cardioacceleratory peptide (Tublitz and Sylvester, 1990). Similarly, Westbrook et al (1993) report a number of neurons other than the well-described LNSC III and the VM-NSC that temporarily express a PTTH-immunoreactive peptide in the Manduca sexta central nervous system. Interestingly, somata that by position and their transitory pattern of PTTH expression correspond to the Manduca neurons could also be detected in the honey bee brain. These are the far lateral protocerebral neurons (cluster 3), as well as the PTTHimmunoreactive somata in the suboesophageal neuromeres and in the prothoracic ganglion. Expression of the PTTH peptide in these neurons, which do not show any apparent relationship to the neuroendocrine axis controlling prothoracic gland activity in the moth, has raised the possibility that PTTH may, in addition to its known steroidogenic function, play additional roles, including neurotransmitter and neuromodulatory functions, at different stages in the insect's life cycle (Bollenbacher et al, 1993). The time pattern of PTTH expression observed in honey bee development by neurons situated in the brain, suboesophageal ganglion and 
prothoracic ganglion provides additional support to this hypothesis.

A strict temporal regulation in the expression pattern of a Bombyx-PTTH-like peptide has also been observed in Drosophila melanogaster (Zitnan et al, 1993). PTTHimmunoreactive neurons were not only detected in the dorsolateral protocerebrum of Drosophila but also in the suboesophageal, thoracic, and even in the abdominal neuromeres. The striking parallels in neuroanatomical organization and developmental programing of PTTH expression in Drosophila with the lepidopteran species have now been further corroborated by our findings in a third group of holometabolous insects, a hymenopteran species. The general picture emerging for the organization of peptidergic neurons expressing a Bombyx PTTH-like peptide in these holometabolans clearly differs from the situation described for the hemimetabolous orthopteran, Loc usta migratoria, where a large number of small peptidergic neurons in the pars intercerebralis showed PTTH-immunoreactivity (Goltzené et al, 1992).

The lack of PTTH-immunoreactive material in axons of the honey bee brain makes it difficult to assess which of the neurons expressing a Bombyx PTTH-like peptide project into the corpora cardiaca or corpora allata. Absence of axonal immunostaining, however, fits into an emerging picture of postembryonic differentiation of the honey bee brain, and corresponds to findings recently obtained for a biogenic amine (Boleli et al, 1995) which is capable of stimulating juvenile hormone release in vitro from corpora allata of Apis mellifera larvae (Rachinsky, 1994). Interestingly, the PTTHimmunoreactive cells in the ventral bridge connecting the corpora allata were found in a position quite similar to serotoninimmunoreactive cells (Boleli et al, 1995). Their products could, thus, be directly released into the hemolymph to activate prothoracic gland projections that terminate in the vicinity of the corpora allata (Boleli, unpublished). The question, thus, becomes whether a fully functional neuroendocrine axis is actually present in honey bee larvae and pupae, or whether neurosecretory cells in the vicinity of the corpora allata function as regulators of gland activity.

\section{ACKNOWLEDGMENTS}

We thank A Mizoguchi (Nagoya, Japan) for kindly providing the antiserum against Bombyx mori PTTH. This research was financially supported by the Deutsche Forschungsgemeinschaft (grant $\mathrm{Ha} 1625 / 1-4)$, and by a CAPES/DAADscholarship to ICB.

\section{Résumé - Présence d'un peptide ana-} logue de l'hormone prothoracotrope dans le système nerveux en cours de développement de l'abeille (Apis mellifera $\mathrm{L}$ ). L'expression et la sécrétion de l'hormone prothoracotrope (PTTH) par les cellules neurosécrétrices de la pars intercerebralis jouent un rôle clé dans la mue et la métamorphose des insectes. Chez les insectes hautement sociaux, la différenciation des castes fait partie intégrante de la métamorphose et est régulée par une modulation spécifique à la caste des teneurs en hormone juvénile et en ecdystéroïde. Pour comprendre la structure de la voie neuroendocrine chez l'insecte social, nous avons recherché la présence d'un peptide potentiellement prothoracotrope dans le cerveau, le complexe rétrocérébral et les ganglions ventraux des larves et des nymphes d'abeille, à l'aide d'un anticorps dirigé contre la PTTH de $30 \mathrm{kDa}$ du ver à soie, Bombyx mori (Mizoguchi et al, 1990).

La présence d'un peptide analogue, la PTTH, a été détectée dans le cerveau, les neuromères subosophagiens et le ganglion prothoracique chez les larves de dernier stade et les nymphes d'abeilles. À la fin de la phase de filage du cocon, 20 à 24 neurones exprimaient dans le cerveau le pep- 
tide analogue à la PTTH. Le nombre de neurones immunoréactifs à la PTTH dans le cerveau varie au cours du développement. Après la nymphose, un seul neurone par hémisphère continue à exprimer le phénotype PTTH, ce qui indique la fin de l'expression du peptide dans de nombreux neurones nymphaux. Dans le ganglion subœsophagien aussi, le nombre de neurones immunoréactifs à la PTTH change après la nymphose. Le pattern de leurs projections n'a pu être tracé car nous n'avons pas pu détecter de matériel immunoréactif à la PTTH dans les axones qui partent des corps cellulaires du cerveau immunomarqué. La question reste ouverte de savoir si les neurones exercent une fonction régulatrice dans la métamorphose de l'abeille et le déterminisme des castes ou s'ils acquièrent plus tard des fonctions encore inconnues. La détection des cellules immunoréactives à la PTTH dans le voisinage des corpora allata suggère cependant la possibilité que le peptide soit mis directement en circulation dans l'hémolymphe et que la synthèse de l'ecdystéroïde soit stimulée dans les glandes prothoraciques proches.

\section{Apis mellifera / neuropeptide / métamor- phose / hormone prothoracotrope}

\section{Zusammenfassung - Vorkommen eines PTTH-ähnlichen Peptids im sich ent- wickelnden Nervensystem der Honigbiene} (Apis mellifera L). Expression und Ausschüttung des prothorakotropen Hormons (PTTH) durch neurosekretorische Zellen in der Pars intercrebrales hat eine Schlüsselfunktion bei der Häutung und der Metamorphose von Insekten. Bei den hoch-eusozialen Insekten ist die Ausbildung der unterschiedlichen Kasten-Phänotypen in die Metamorphose integriert und wird durch kastenspezifische Modulation der Juvenilhormon- und Ecdysteroid-Titer reguliert. Um die Struktur der neuroendokrinen Achse bei sozialen Insekten zu verstehen, unter- suchten wir das Vorkommen eines Peptids mit möglicherweise prothorakotroper Funktion im Gehirn, dem retrocerebralen Komplex und den Ventralganglien von Larven und Puppen der Honigbiene (Apis mellifera L). Die immuncytochemischen Analysen wurden mit einem spezifischen Antikörper gegen das $30 \mathrm{kDa}$ PTTH des Seidenspinners Bombyx mori durchgeführt (Mizoguchi et al, 1990).

Ein PTTH-ähnliches Peptid ließ sich im Gehirn, in den Neuromeren des Unterschlundganglions und im Prothorakalganglion nachweisen. Am Ende der larvalen Spinnphase exprimierten im Bienengehirn 20-24 Neurone ein PTTH ähnliches Peptid. Die Zahl der Neurone mit positiver PTTH Immunreaktion änderte sich im weiteren Verlauf der Entwicklung. Nach der Puppenhäutung zeigte nur noch ein Paar Neurone pro Hirnhälfte eine PTTH Immunreaktion. Nach der Puppenhäutung scheint demzufolge in den meisten ehemals PTTHpositiven Neuronen die Peptidexpression von PTTH eingestellt zu werden. Die Zahl der PTTH-immunreaktiven Neurone im Unterschlundganglion änderte sich ebenfalls nach der Puppenhäutung. Das Projektionsmuster der PTTH-exprimierenden Neurone konnte jedoch nicht aufkärt werden, da wir in den Axonen dieser Neurone im Gehirn und Unterschlundganglion kein PTTH-immunreaktives Material nachweisen konnten. $\mathrm{Ob}$ diese Neurone eine regulatorische Funktion bei der Metamorphose und Kastenentwicklung der Honigbienen haben, oder ob sie später eventuell andere Funktionen übernehmen, ist nicht geklärt. Der Nachweis von PTTH-immunreaktiven Zellen in der Nähe der Corpora allata weist jedoch auf die Möglichkeit einer Freisetzung solcher Peptide in die Hämolymphe hin, die dann die Ecdysteroid -Synthese in den benachbarten Prothoraxdrüsen stimulieren könnten.

PTTH, Insekten-Neuropeptide / Corpora allata / Insektenmetamorphose / Apis mellifera 


\section{REFERENCES}

Adachi T, Yamada T, Iwami M, Kataoka H, Suzuki A, Ishizaki H (1994) Structure and expression of the gene for the prothoracicotropic hormone of the silkmoth Bombyx mori. Eur J Biochem 220, 633643

Boleli IC, Hartfelder K, Simoes Z.L.P (1995) Serotonin-like immunoreactivity in the central nervous system of honey bee (Apis mellifera) larvae and pupae. Zoology 99, 58-67

Bollenbacher WE, Granger NA (1985) Endocrinology of the prothoracicotropic hormone. In: Comparative Insect Physiology, Biochemistry, and Pharmacology (GA Kerkut, LI Gilbert, eds), vol 7, Pergamon Press, New York, 109-151

Bollenbacher WE, Gray RS, Muehleisen DP, Regan SA, Westbrook AL (1993) The biology of the prothoracicotropic hormone peptidergic neurons in an insect. Am Zool 33, 316-323

Bowen MF, Saunders DS, Bollenbacher WE, Gilbert LI (1984) In vitro reprogramming of the photoperiodic clock in an insect brain-retrocerebral complex. Proc Natl Acad Sci, USA, 81, 5881-5884

Copenhaver PF, Truman JW (1986) Identification of cerebral neurosecretory cells that contain eclosion hormone in the moth Manduca sexta. J Neurosci 6 , 1738-1747

Dai J-D, Mizoguchi, A Gilbert LI (1994) Immunoreactivity of neurosecretory granules in the brainretrocerebral complex of Manduca sexta to heterologous antibodies against Bombyx prothoracicotropic hormone and bombyxin. Invertebr Reprod Dev 26, 187-196

Gelman DB, Thyagaraja BS, Kelly TJ, Masler EP, Bell RA, Borkovec AB (1992) Prothoracicotropic hormone levels in brains of the European corn borer, Ostrinia nubilalis: diapause vs the non-diapause state. J Insect Physiol 38, 383-395

Gilbert LI (1989) The endocrine control of molting: the tobacco hornworm, Manduca sexta, as a model system. In: Ecdyson (J Koolman, ed), Thieme, Stuttgart, 448-471

Goltzené F, Holder F, Charlet M, Meister M, Oka T (1992) Immunocytochemical localization of Bombyx-PTTH-like molecules in neurosecretory cells of the brain of the migratory locust, Locusta migratoria. Cell Tissue Res 269, 133-140

Gray RS, Muehleisen DP, Katahira EJ, Bollenbacher WE (1993). A 28-kDa neuropeptide from Manduca sexta: relationship to insect prothoracicotropic hormone. Cell Mol Neurobiol 13, 39-57

Gray RS, Muehleisen DP, Katahira EJ, Bollenbacher WE (1994) The prothoracicotropic hormone (PTTH) of the commercial silkmoth, Bombyx mori, in the CNS of the tobacco hornworm, Manduca sexta. Peptides 15, 777-822
Hartfelder K (1993) Structure and function of the prothoracic gland in honey bee (Apis mellifera $\mathrm{L}$ ) development. Invertebr Reprod Dev 23, 59-74

Hartfelder K, Hanton WK, Bollenbacher WE (1994) Diapause-dependent changes in prothoracicotropic hormone-producing neurons of the tobacco hornworm Manduca sexta. Cell Tissue Res 277, 68-78

Hartfelder K, Köstlin K, Hepperle C (1995) Ecdysteroid-dependent protein synthesis in caste-specific developement of the larval honey bee ovary. Roux's Arch Dev Biol 205, 73-80

Ishizaki H, Suzuki A (1992) Brain secretory peptides of the silkworm, Bombyx mori: Prothoracicotropic hormone and bombyxin. In: Progress in Brain Research (J Joose, RM Buijs, FJH Tilders, eds), vol 92, Elsevier, Amsterdam, 1-14

Kelly TJ, Thyagaraja BS, Bell RA, Masler EP (1995) A novel low molecular weight ecdysiotropin in post-diapause, pre-hatch eggs of the gypsy moth, Lymantria dispar L. (Lepidoptera: Lymantriidae). Regulat Peptides 57, 253-261

Mizoguchi A, Oka T, Kataoka H, Nagasawa H, Suzuki A, Ishizaki H (1990) Immunohistochemical localization of prothoracicotrpic hormone-producing neurosecretory cells in the brain of Bombyx mori. Dev Growth Diff 32, 591-598

Muchleisen DP, Gray RS, Katahira EJ, Thomas MK, Bollenbacher WE (1993) Immunoaffinity purification of the neuropeptide prothoracicotropic hormone from Manduca sexta. Peptides 14, 531-541

Muehleisen DP, Katahira EJ, Bollenbacher WE (1994) Physical characteristics of the cerebral big prothoracicotropic hormone from Manduca sexta. Experientia $50,159-163$

Noguti T, Adachi-Yamada T, Katagiri T, Kawakami A, Iwami M, Ishibashi J, Kataoka H, Suzuki A, Go M, Ishizaki H (1995) Insect prothoracicotropic hormone: a new member of the vertebrate growth factor superfamily. FEBS Lett 376, 251-256

O'Brien MA, Katahira EJ, Flanagan TR, Arnold LW, Haughton G, Bollenbacher WE (1988) A monoclonal antibody to the insect prothoracicotropic hormone. J Neurosci 8, 3247-3257

Pak JW, Chung KW, Lee CC, Namkoong KY, Koolman J (1992) Evidence for multiple forms of the prothoracicotropic hormone in Drosophila melanogaster and indication of a new function. $J$ Insect Physiol 38, 167-176

Rachinsky A (1994) Octopamine and serotonin influence on corpora allata activity in honey bee (Apis mellifera) larvae. J Insect Physiol 40, 549-554

Rachinsky A, Engels W (1995) Caste development in honeybees (Apis mellifera): juvenile hormone turns on ecdysteroids. Naturwissenschaften 82, 378-379

Rachinsky A, Strambi C, Strambi A, Hartfelder K (1990) Caste and metamorphosis: hemolymph titers of juvenile hormone and ecdysteroids in last instar honey bee. Gen Comp Endocrinol 79, 31-38 
Rembold H (1987) Caste-specific modulation of juvenile hormone titers in Apis mellifera. Insect Biochem 17. 1003-1006

Richter K (1992) Prothoracicotropic activity in the brain of the cockroach Periplaneta americana. $J$ Insect Physiol 38, 349-355

Rybcynski R, Mizoguchi A, Gilbert LI (1996) Bombyx and Manduca prothoracicotropic hormones: an immunological test for relatedness. Gen Comp Endocrinol 102, 247-254

Tublitz NJ, Sylvester AW (1990) Postembryonic alteration of transmitter phenotype in individually identified peptidergic neurons. J Neurosci 10, 161-168

Westbrook AL, Bollenbacher WE (1990) The development of identified neursecretory cells in the tobacco hornworm, Manduca sexta. Dev Biol 140 , 291-299

Westbrook AL, Haire ME, Kier WM, Bollenbacher WE (1991) Three-dimensional achiteture of identified cerebral neurosecretory cells in an insect. $J$ Morphol 208, 161-174

Westbrook AL, Regan SA, Bollenbacher WE (1993) Developmental expression of the prothoracicotropic hormone in the CNS of the tobacco hornworm Manduca sexta. I Comp Neurol 327, 1-16

Zitnan D, Sehnal F, Brian PJ (1993) Neurons producing specific neuropeptides in the central nervous system of normal and pupariation-delayed Drosophila. Dev Biol 156, 117-135 